Indonesian Journal of EFL and Linguistics

Vol. 6 No. 1, 2021

eISSN: 2503-4197, pISSN: 2527-5070

www. indonesian-efl-journal.org

doi: http://dx.doi.org/10.21462/ijefl.v6i1.364

\title{
Critical Digital Literacy: EFL Students' Ability to Evaluate Online Sources
}

\author{
Sary Silvhiany \\ Universitas Sriwijaya, Indonesia \\ e-mail: ssilvhiany@unsri.ac.id \\ Siti Huzaifah \\ Universitas Sriwijaya, Indonesia \\ e-mail: Siti.huzaifah@fkip.unsri.ac.id \\ Ismet \\ Universitas Sriwijaya, Indonesia \\ e-mail: ismet@fkip.unsri.ac.id
}

\begin{abstract}
:
The advancement of Internet-based technologies and the new media ecology have contributed to the increased reliance on online sources in both the academic and the non-academic contexts. This study investigated how students evaluated the credibility of online information and the bias that might have influenced the content of the information. $152 \mathrm{EFL}$ students responded to the online critical literacy assessment, which consisted of six tasks: evaluating the credibility of visual information, evaluating WhatsApp message, comparing and evaluating websites, distinguishing between news and sponsored content, evaluating the credibility of claim in a YouTube video, and evaluating an Instagram post. The results of the study showed that the students were easily deceived by the online information they read from various online media. They particularly struggled to detect the unsubstantiated claims from the YouTube video. Despite being a generation $Z$ who frequently used social media and various online sources in their daily lives, the students could not critically evaluate the claims posted on these platforms. Implications of this study
\end{abstract}


Sary Silvhiany, et al

include the need to incorporate critical digital literacy in the language skill courses and deliberate exposure to strategies in evaluating online sources.

Keywords: critical literacy, digital information, pre-service teachers, reading, EFL learners

\section{INTRODUCTION}

The advancement of communication devices and Internet-based information has dramatically shifted the landscape of information access. In fact, since the turn of the millennium, people have increasingly relied on online information. This also affects people's literacy practices, which are dominantly online-based activities. This is also supported by the current data from the Reuters digital report (Newman, 2020), which shows that over $72 \%$ of the respondents from 7 countries representing the populated continents received their news from side door access. These side doors include social media, search engines, mobile alerts, aggregators, and email.

The increasingly popular social media as the digital sources of information have drawn traditional news outlets as well as contemporary news sites and other personal blogs to link their news and other types of writing to the social media platform such as Facebook and Twitter. The share buttons usually found under news articles have made it easier for people to share news through their social media accounts.

Since a decade ago, (Purcell et al., 2010) have noticed the shift in the way consumers access their information. Consumers have moved from accessing the news at the fixed place and time to the customized news that they can access at their convenient time. In the same vein, (Kalogeropoulos et al., 2019) also found the increased reliance on the distributed form of discovery through the news posted on social media. Thus, social media sites have become a crucial source of information. They function more than just for personal networking platforms.

The prevalence of social media as the source of information comes with a challenge. In the wake of 2016 US presidential election, people have realized the danger of misinformation to our democracy. Social media have been criticized as the fertile ground for the spread of fake news and other types of misinformation, especially during the election period when competing interests clashed (Lee, 2018; MacFarquhar, 2016).

More than ever, the spread of misinformation has reached many other areas in our life, not just politics. In this pandemic era, for instance, studies investigating the Covid19 information in YouTube and other social media have found a staggering number of fake news and other misinformation on this topic (Brennen et al., 2020; Li et al., 2020; Schaeffer, 2020). The World Health Organization (WHO) has 
popularized the term infodemic to describe misleading information that is as dangerous as the pandemic itself (Who.int, 2021). The misinformation on social media, such as the use of Clorox and chloroquine to cure the Covid19, has resulted in dangerous health situations among people who follow the suggestions (Lovelace, 2020). Considering the negative outcomes, WHO has issued a fight against all types of misinformation regarding the novel coronavirus pandemic.

The two above-mentioned misinformation issues are only the tip of the iceberg. The open-access information and the advancement of communication technologies have allowed different types of information to permeate into people's daily life through the layers of social media and mobile news interconnections. Despite the benefits of having the information at our fingertips, we become vulnerable to various kinds of misinformation.

Considering our increased reliance on online sources, literacy researchers have focused their attention on how people access, comprehend, and evaluate online information. Studies have shown discouraging facts about students' ability to evaluate the information available on online platforms. In the USA, a large assessment of online civic reasoning conducted by (McGrew et al., 2018) to the Middle School, High School, and College students indicate that students struggled to determine the credibility of the information. Most students failed to evaluate who was behind the information. Instead, they focused on the surface features of the online platform. It confirmed Sundar's research finding (Sundar, 2008) that youths relied on the websites' surface characteristics when they evaluated the credibility of the information.

In the Indonesian context, a growing concern for the hoax and other types of misinformation emerged as we have experienced the hostile effect of negative campaigns during the general election. Moreover, the intensity of misinformation has also increased during the pandemic time. The information, in which many of the sources were from outside of Indonesia, was translated from English. This makes it even harder for Indonesian people to evaluate the credibility of the information.

While online information credibility has been the focus of literacy assessment in many countries, it has not been widely addressed in Indonesia educational context. Our teaching and assessment still emphasize how students and teachers use digital literacy in the classroom (Rusydiyah et al., 2020). Meanwhile, a few other studies explored critical literacy in non-digital form (Aimah \& Purwanto, 2019; Gustine, 2013; Mbau \& Sugeng, 2019; Setyaningsih, 2019). This present article is aimed at filling this gap by examining the Indonesian EFL students' ability to evaluate online information from multiple digital platforms. The article seeks to investigate:

1. How do students of English Education major evaluate the online critical literacy assessment?

2. What task do the students consider to be the most challenging? 
Sary Silvhiany, et al

\section{LITERATURE REVIEW}

The conception of literacy has evolved over the years. Before the turn of the millennium, literacy was widely defined as the ability to comprehend printed material. As technology is advancing to digital forms, literacy quickly evolves to encompass all the literate practices and communication mediated by both paper and pixels. This section discusses the impact of technology development on literacy and the need to develop the skills in evaluating online sources.

\subsection{Literacy Practices in the New Media Ecology}

The development of communication technologies has reshaped our literate life as we move into more digitally-mediated practices. Even though the Internet has been around since 1960, the noticeable individual use of the Internet started in the 1990s along with the increased access to personal computers. It was estimated that only 0.5 percent of the population were connected to the Internet and was mostly concentrated in the more developed countries. By 2015, almost half of the world's population connected to online platforms (Roser, 2015).

As smartphones continue to be more affordable for many people, access to internetbased communication is increasing. A qualitative study examining the $22 \mathrm{UK}$ residents' news behavior, attitudes, and online journeys highlight some interesting findings regarding the interaction between users, technology, and information (Office of Communication, 2016). First, online information consumption was facilitated mainly by smartphones which encouraged passive consumption of information through scrolling, swiping, and watching behaviors rather than purposive searching of information. Second, the continuous streams of news flowing to smartphones were facilitated by a wide range of social media networks and other online platforms, thus, making the newsfeed a ubiquitous interface that keeps people in the mobile apps. Third, social media contents have blurred the boundary between news, entertainment, and other types of information, which heightened the difficulty in critically evaluating the information. Finally, most of the respondents were aware of the potential bias and misinformation from the online sources. However, most of them did not put enough effort to practice critical thinking when accessing the news.

Literacy scholars argue that students need to develop critical online information literacies to be effective users of information in the digital age (Leeder, 2019; McDowell \& Vetter, 2020). This is because most students rely on online information for nearly all aspects of their life. A large-scale survey conducted by Head, DeFrain, Fister, and MacMillan to 5,844 students from 11 universities across the USA explored how the students engaged with news and the difference between their news-for-academic practices and news-for-personal and civic life. The results showed that Facebook was the dominant source of the news the students accessed, followed by Snapchat, and YouTube. Through the interview, the researchers also 
found that the news was dominantly delivered through multiple platforms to the students' mobile alerts (Head et al., 2019).

The ubiquity of Internet-based literacy activities has contributed to the shift from dominantly printed texts to online-based texts. Digitally-mediated literacy practices require competencies specific to the online environment (Silvhiany, 2019). Digital literacy scholars propose some competencies necessary for active engagements in the $21^{\text {st }}$ century. Hobbs, for example, emphasized the ability to analyze information from multiple sources by paying attention to who is behind the information, the purpose and point of view, and to evaluate the quality and credibility of the sources (Hobbs, 2010).

Other researchers, such as Potter and Gilje, Alvermann, Nagle, and Chaka (Alvermann, 2017; Chaka, 2019; Nagle, 2018; Potter \& Gilje, 2015) argue for the need to pay attention to the intertwining literacy practices and social media texts. Chaka describes social media as part of semio-technologies that assemble signs, linguistic symbols, and cultural practice within a system of data in which people interact and construct meaning (Chaka, 2019). As youths engage more with multiple social media as the means of communication and civic participation, scholars and educators have to consider how to support critical inquiries within these platforms.

Alvermann (2017:336) suggests critical inquiry instruction to "engage learners in evaluating social media texts ... for the purpose of identifying underlying assumptions not previously considered ... to provide practice in arriving at wellreasoned analyses about the content; without ruining their enjoyment of it." (Alvermann, 2017). In line with the critical inquiry, Potter and Gilje (2015) add the component of curation as an important literacy practice in social media environment. They believe, "Curatorship and learning identity in new media as an emerging literacy practice in which young people's agentive activity is performed in and on the world (pp. 123 - 124)."

The emerging social media-related literacy practices have also required at least four competencies, which include the ability to evaluate the credibility of the websites by considering who is behind the sources (Damico \& Baildon, 2011); to determine trustworthiness, readability, and usefulness (Baildon \& Baildon, 2012); to navigate the online landscape (Breakstone et al., 2019) and to employ digital practices and critique online information (Beach et al., 2020).

\subsection{Web Credibility Evaluation}

The availability of wireless Internet and the emergent of new media ecology have enabled individuals to choose information from a wide range of sources, such as video clips, social media posts, blog entries, news articles, and many more. On the one hand, limitless options can be an empowering tool of learning. On the other hand, these online sources can be overwhelming and demand users to more vigilant about the online information. 
A survey conducted by Reuters Institute in 2020 (Newman, 2020) in thirty-eight countries across six continents highlights the types of social media that were seen as the most problematic platform in terms of the spread of information. The two biggest conduits of disinformation were Facebook and WhatsApp, followed by Google and Twitter.

In the past decade, researchers have focused on how students of various levels of education navigated information from multiple sources. At the university level, studies investigating how students assessed the credibility of information showed a bleak view of their performance. One of the early studies concerning university students' use of online information and their ability to evaluate the sources was conducted by Metzger, Flanagin, and Zwarun (Metzger et al., 2003). They examined the students' frequency of using the Internet, the general and academic purposes of using the Internet, and their perceptions about the relative credibility of information sources. Their findings suggest that even though students used web-based information just as much as an academic journal, the students rarely verified the information they got from the web. Metzger, Flanagin, and Zwarun (2003) concluded that, "Many students take a relatively uninformed view of online information credibility" (P. 287.)

The study conducted by Hargittai, Fullerton, Menchen-Trevino, and Thomas contributed to our understanding of factors influencing how users evaluate the credibility of the sources (Hargittai et al., 2010). Based on the analysis of both quantitative (a survey to 1,060 first-year students) and qualitative data (in-person observations and interviews), the researchers found that the participants trusted in the search engines when completing the assigned tasks, particularly the first information that came up in the search engine page. The participants also considered popular brands, such as Google, Yahoo, Wikipedia, as the signifier of information quality. The study also highlights that the different skill levels affect the credibility assessment. Participants who were at a high skill level in terms of digital literacy ability demonstrated a heightened level of satisfaction in doing the tasks of assessing information credibility.

More recent research explores how students evaluate climate change-related information from the Internet. In their study with two preservice teachers, Damico, Panos, and Baildon examined how the students engaged in critical literacy practices of textual critique. Qualitative analysis of the students' discussion shows that the students engaged in critical literacy practice by employing three ways of textual critique, i.e., determining the purpose of each source, evaluating claims and evidence, and evaluating author techniques. Despite these similarities in textual analysis, the students' reader reflexivity differed due to their backgrounds, personal experiences, and beliefs (Damico et al., 2018).

In the Indonesian context, not much has been scholarly explored regarding students' ability to assess online information. One study investigated how 16 undergraduate 
and graduate students, aged 19 to 29 years, distinguished fake news and news written in Bahasa Indonesia (Khairunissa, 2020). The researcher found that overall the participants could identify which ones were fake news and which ones were factual news. The study also highlights the interconnection between participants' interest and their willingness to evaluate the sources. The participants only did further research of the sources when they were interested in the topics.

Considering the increased reliance on online sources, particularly the sources written in English for both academic and civic participation in the digital age, it is high time to understand how students process and evaluate the credibility of online information.

\section{RESEARCH METHODOLOGY}

The present study employed a case study approach to examine how pre-service teachers performed in evaluating online information. Their performance was measured with the online critical literacy assessment (OCLA) designed for EFL students at the tertiary level. OCLA has been designed in multiple stages, which include the review of the existing research on online literacy to map the domain of information sources assessment, need analysis for online critical literacy for EFL students, expert review, and pilot testing (Silvhiany et al., 2021).

This study was conducted at a teacher preparation program in one of the state universities in Indonesia. Pre-service teachers in the sophomore ( $3^{\text {rd }}$ semester), junior $\left(5^{\text {th }}\right.$ semester $)$, and senior $\left(7^{\text {th }}\right.$ semester $)$ years participated in this study. There is a total of 152 students involved in this study. The freshmen students were not involved in this study because they were just starting the program. The start of the program for the first-year student was pretty late because of the Covid19 school closure.

The study relied on online critical literacy assessment to examine the pre-service teachers' ability to evaluate online information. The online critical literacy assessment (OCLA) was developed to capture several aspects of critical literacy in the online environment. The OCLA used in this study has been validated and pilottested (Silvhiany et al., 2021). The OCLA is comprised on 6 tasks, namely, analyzing visual information, evaluating claims on WhatsApp messages, comparing and evaluating websites, distinguishing between advertisements and articles on an online magazine homepage, evaluating the credibility of claims on YouTube, and evaluating claims on Instagram. Participants were allowed to use English, Indonesian, or translanguaging to write their responses. It would avoid the language barrier that might hinder their ability to express their evaluation of the tasks.

Data from the online critical literacy was analyzed using frequency analysis to determine the preservice teachers' performance on each task. Rubrics were developed as the standard for assessing the students' responses in each task. The 
rubrics contain explanations for the four categories: mastery, emerging, beginning, and incorrect.

Each response was read and assessed by the three researchers to ensure the validity and trustworthiness of the results. The analysis of the response was compared among the researchers. Since the rubrics were clear, there were only a few disparities that were resolved with discussion.

In addition to the online critical literacy assessment, focus group discussions were conducted to each group of participants (a sophomore cohort, a junior cohort and the senior cohorts) to know their perceptions about which task was the most challenging and what strategies they used when they completed the task. The focus group discussions lasted between 30 to 40 minutes and were conducted through zoom meeting.

\section{FINDINGS}

\subsection{Analyzing Visual Evidence}

A proverbial sentence "a picture is worth a thousand word" is commonly used to describe the importance of visual support in making persuasive communication. In fact, social media sites are littered with pictures that users use for various purposes, from entertainment and preserving memories to more serious purposes, such as news and political statement. Because of the increased use of images in digitally mediated communication, it is necessary to know how students can critically evaluate the images they found online.

In the first task of the online critical literacy assessment, the preservice teachers were asked to evaluate the visual information posted in Imgur, an image-sharing website. In 2015, a person uploaded a picture of malformed daisies in Imgur. This picture became popular on Twitter and was shared by hundreds of people claiming that the nuclear facility in Fukushima Daiichi leaked radiation to the environment and caused environmental damage, as seen in this figure 1.

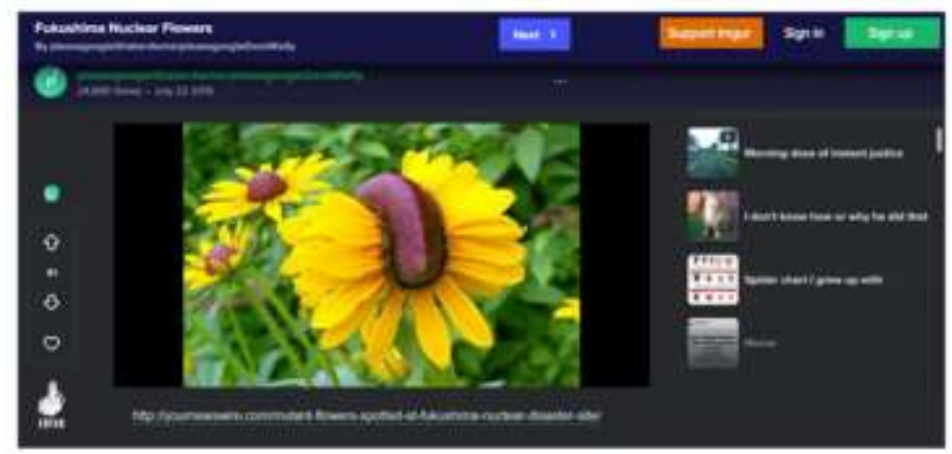

Figure: 1 Visual Evidence Analysis Task 
As shown in table 1, about 23.7 percent of the students believed that the image was strong evidence of the nuclear damage near Fukushima Daiichi. Even though over half of the respondents thought the claim was unsubstantial, only $14.7 \%$ could provide strong analytical reason (the Mastery level). To achieve the mastery level, students have to problematize the source of the post and the photograph. Most students' responses were in emerging and beginning category because their explanation did not question the credibility of the sources or only provided incoherent reasoning.

Table: 1 Students' responses to the visual evidence

\begin{tabular}{lcccc}
\hline Students & $\begin{array}{c}\text { Mastery } \\
(\mathbf{\%})\end{array}$ & $\begin{array}{c}\text { Emerging } \\
(\mathbf{\%})\end{array}$ & $\begin{array}{c}\text { Beginning } \\
(\mathbf{\%})\end{array}$ & $\begin{array}{c}\text { Incorrect } \\
(\mathbf{\%})\end{array}$ \\
\hline Sophomore & 2.8 & 36 & 30.6 & 30.6 \\
Junior & 20 & 36 & 28 & 19 \\
Senior & 16.7 & 30.3 & 27.3 & 25.8 \\
Total Percentage & $\mathbf{1 4 . 5}$ & $\mathbf{3 3 . 6}$ & $\mathbf{2 8 . 3}$ & $\mathbf{2 3 . 7}$ \\
\hline
\end{tabular}

\subsection{Evaluating Claim on WhatsApp message}

In the second task, the students were asked to evaluate the claim regarding preventive measures for the COVID19 virus forwarded in the WhatsApp chat. This messaging app is the most popular app for communication in Indonesia and many other countries, particularly in Asia. Information on various fields circulates within this mobile application. Therefore, the ability to analyze and evaluate the information within WhatsApp chat is crucial. Students had to analyze the credibility of the information by focusing on who was behind the information.

Table: 2 Students' responses to the information from WhatsApp Message

\begin{tabular}{lcccc}
\hline Students & $\begin{array}{c}\text { Mastery } \\
(\boldsymbol{\%})\end{array}$ & $\begin{array}{c}\text { Emerging } \\
(\boldsymbol{\%})\end{array}$ & $\begin{array}{c}\text { Beginning } \\
(\boldsymbol{\%})\end{array}$ & $\begin{array}{c}\text { Incorrect } \\
(\boldsymbol{\%})\end{array}$ \\
\hline Sophomore & 5.6 & 53 & 19.4 & 22 \\
Junior & 18 & 52 & 22 & 8 \\
Senior & 15.2 & 36.4 & 27.3 & 21.2 \\
Total Percentage & $\mathbf{3 1 . 9}$ & $\mathbf{4 5 . 4}$ & $\mathbf{2 3 . 7}$ & $\mathbf{1 7 . 1}$ \\
\hline
\end{tabular}

As shown in Table 2, most respondents correctly identified that the message was not strong evidence of preventive measures for the COVID19 virus. However, most responses did not address the issue of who was behind the message. The responses mostly questioned the credibility of the sources, but neither identified the authorship nor provided a complete explanation. Instead of addressing the issue of the authorship credibility, some of the preservice teachers evaluated WhatsApp in 
general. For instance, one of them wrote, "Not all messages on WhatsApp are always correct. Many of these messages are fake and have no clear source". Others used their previous knowledge about COVID19, as can be seen from this response:

'No, it doesn't. The message hasn't contained any explanation the reason why we must avoid those type of cold drinks and preserved food. And this isn't related at all to prevent covid19. And if want to talk about the reality, the important thing to do is wearing a mask."

The above statement is an example of how students compared their knowledge and experience with the statement in the WhatsApp post. However, it lacked the evaluation of the source.

The responses would be categorized as the mastery level if they addressed the credibility of the source. An example of the mastery category includes questioning who is behind the information. One student wrote, "I think this source is not trustworthy because it doesn't say where the source is from. It mentioned the name of a doctor, but we don't know if he is a real doctor."

Some others went all the way by googling the name of the doctor to find the sources and browse the government official Covid19 website (the respondent mentioned https://covid19.nj.gov) to find out the fact about the association between cold drink and Covid-19. Overall, the preservice teachers showed awareness of Covid19 transmission and preventions. However, there is still $17.1 \%$ of them who believed that the source was credible.

\subsection{Comparing and Evaluating websites}

Students increasingly rely on online information and data for their school assignments and various academic tasks. Google search engine is usually the first go-to place to search for information students need for their papers and another research assignment. Google and other search engines will direct users to the information based on the keywords they put in the search and provide the list of websites in the order of relevance. The whole series of algorithm rank the information appeared on the Google search. However, this rank does not guarantee that all the information listed possesses the same level of credibility. The popularity and interesting display of a website may not determine the credibility of the website.

In this task, the preservice teachers have presented the task to compare and analyze two websites that provide information about climate change. The first website is from Exxon Mobile, while the second one is from the U.S. Energy Information Administration.

Both websites provide relevant information regarding climate change. The preservice teachers had to evaluate which one was more credible and less bias. The response is categorized into the mastery level if it explains that the first website is 
less trustworthy because the information provided by the oil company might be bias in regard to the information about the impact of energy production on climate change. The response at the mastery level also considers the second website as more trustworthy because it is sponsored by the government. Students who successfully met the mastery criterion responded to the questions by explaining the bias, as can be seen in the following response:

I would prefer the second one which is from eia.gov as the more credible one since it is managed by the government. The first link was written by a company (Exxon mobile) which makes me think they might can't provide actual information and probably has some business thing on it.

The analysis of the responses revealed that most students' responses belong to the emerging category, as shown in table 3.

Table: 3 Students' Responses to Website Analysis

\begin{tabular}{lcccc}
\hline Students & $\begin{array}{c}\text { Mastery } \\
(\mathbf{\%})\end{array}$ & $\begin{array}{c}\text { Emerging } \\
(\mathbf{\%})\end{array}$ & $\begin{array}{c}\text { Beginning } \\
(\mathbf{\%})\end{array}$ & $\begin{array}{c}\text { Incorrect } \\
(\mathbf{\%})\end{array}$ \\
\hline Sophomore & 13.9 & 44 & 22 & 19 \\
Junior & 20 & 40 & 22 & 18 \\
Senior & 19.7 & 37.9 & 22.7 & 29 \\
Total Percentage & $\mathbf{1 8 . 4}$ & $\mathbf{4 0 . 1}$ & $\mathbf{2 2 . 4}$ & $\mathbf{1 9 . 1}$ \\
\hline
\end{tabular}

The students' responses were grouped in emerging category if they correctly chose the second website as the more reliable and less bias by providing the explanation that the second website was a governor-sponsored, without explaining that the first website was sponsored by an oil company.

\subsection{Distinguishing Advertisements and Opinion Articles}

Unlike printed magazines that rely on both advertisement and product (or subscription) as the sources of income, online magazines rely heavily on sponsors to generate income. The advertisement in the online magazine is often creatively incorporated within the articles or section. Thus, making it more challenging for people to distinguish it from the regular article.

In this task, the students were asked to evaluate if the sections appeared in the HuffPost were advertisement or just regular article. They also have to provide an explanation. There were six questions in this task. Figure 4 shows three out of six sections on the homepage. 


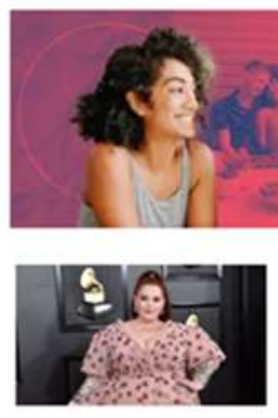

How Ordering Food Delivery Became My

Pregnancy's Secret Weapon

Paid For By Grubhub

For The Last Time, Being Thin Is Not A Fashion

Statement

Images presented to us on television, social media and best-dressed lists

by and large value size over style.

By Jamle Feldman

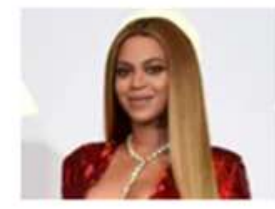

12 Beauty Products The

'Black Is King' Makeup

Artists Swear By

Figure: 2 Questions of distinguishing advertisement and opinion article

The response is categorized as mastery level if they can correctly identify which section is an advertisement or sponsored articles/section by providing the clues from the texts, such as the small writing "paid by" and other visual clues. As table 4 shows, the incorrect responses in these tasks are pretty high. Almost half of the respondents thought that the first section (task 4.a) "How ordering food delivery became my pregnancy's secret weapon", as a regular article about pregnancy. In fact, it is a sponsored article about the food delivery service. Students who could answer this task correctly pointed out the clue written on the right below the title "Paid for by Grubhub". Grubhub is not a popular food delivery app in Indonesia. However, skilled readers would pay attention to the context clue, such as the sponsor of the article.

Task 4.b. is an article about fashion and women's body image. In this task, many students could correctly identify that this is an article instead of an advertisement. Successful responses cited some characteristics of the article. For example, there was the name of the writer, and that the article did not advertise a product. There were only $23 \%$ of incorrect answers for this task.

In task 4.c the percentage of the incorrect responses was pretty high (41.4\%). Most students were deceived by the hidden advertisement woven into an article. In online magazines, such as Huffpost and Buzzfeed, advertisements are often woven into an article. Task 4.c is an example of a sponsored article that describes an artist's beauty regime. The author used a popular figure to endorse beauty products. This sponsored article is particularly aimed at the targeted audience of people of color. 
Table: 4 The overall results of incorrect responses on distinguishing advertisement and article

\begin{tabular}{lccc}
\hline Students & $\begin{array}{c}\text { Task 4.a } \\
(\boldsymbol{\%})\end{array}$ & Task 4.b & Task 4.c \\
\hline Sophomore & 52.5 & 13.6 & 55.6 \\
Junior & 54 & 20 & 46 \\
Senior & 44 & 24.2 & 30.3 \\
Total Percentage & $\mathbf{4 4 . 8}$ & $\mathbf{2 3}$ & $\mathbf{4 1 . 4}$ \\
\hline
\end{tabular}

\subsection{Evaluating Credibility of Claims on YouTube}

Considering the widespread use of YouTube videos as resources for information on current events, this online critical literacy assessment presented a YouTube video regarding the COVID19 pandemic. The students were asked to evaluate whether the video provides convincing facts or evidence that the COVID19 was planned. The online assessment form showed the image of the YouTube account with its description and the first image of the video with the link to the video. The responses were categorized into the mastery level if they articulated a sound reason and provided a complete explanation why they might not trust the video. Respondents can focus on several aspects related to insufficient context or information, including:

- There is insufficient information about the person who created the video

- There is insufficient information about the YouTuber and their view

- The claims made by the YouTuber cannot be verified or against the official information

- The student provides a coherent explanation of how the above-mentioned factors influence the credibility of the video.

The analysis of the students' responses shows that students struggle to evaluate the claims made by the video creator. As table 5 shows, over $38 \%$ of the students were duped by the video. They believed in the claims that Covid19 pandemic was planned by some big names, such as Bill Gate and the Rockefeller family, who wanted to take advantage of the spread of the virus. The unsubstantiated claims are, of course, not true. Many fact-checker sites have labeled the video as hoax. However, this YouTube video is still around and garnered hundreds of thousands of views.

Table: 5 Students' Evaluation of YouTube Video Claims

\begin{tabular}{lcccc}
\hline Students & $\begin{array}{c}\text { Mastery } \\
(\mathbf{\%})\end{array}$ & $\begin{array}{c}\text { Emerging } \\
(\mathbf{\%})\end{array}$ & $\begin{array}{c}\text { Beginning } \\
(\mathbf{\%})\end{array}$ & $\begin{array}{c}\text { Incorrect } \\
(\boldsymbol{\%})\end{array}$ \\
\hline Sophomore & 2.8 & 27.8 & 36 & 33.3 \\
Junior & 14 & 38 & 10 & 38 \\
Senior & 3 & 33.3 & 22.7 & 40.9 \\
Total Percentage & $\mathbf{6 . 6}$ & $\mathbf{3 3 . 6}$ & $\mathbf{2 1 . 7}$ & $\mathbf{3 8 . 2}$ \\
\hline
\end{tabular}

Indonesian Journal of EFL and Linguistics, 6(1), 2021 
Sary Silvhiany, et al

\subsection{Evaluating Claim on Social Media}

Social media sites, such as Facebook, have transformed from networking sites that connect relatives and old friends in a heartfelt reunion to becoming a space to promote products and ideologies. Companies and agencies of various kinds use social media to increase their visibility and reach out to their customers. As an increasingly popular social media, Instagram is also used by companies to promote their programs and their images.

The last task in the online critical literacy assessment presents a video from British Petroleum regarding its focus on reimagining energy for net-zero on carbon. The mastery level requires respondents to identify the ownership of the Instagram account and how it can create bias. In this task, the preservice teachers had to think critically to decide if they trusted the video as proof regarding the company's commitment to the environment. They had to provide an analytical response for their answer, which required deep critical thinking beyond what could be inferred from the content of the video.

Table: 6 Students' Evaluation of Instagram's Content

\begin{tabular}{lcccc}
\hline Students & $\begin{array}{c}\text { Mastery } \\
(\mathbf{\%})\end{array}$ & $\begin{array}{c}\text { Emerging } \\
(\mathbf{\%})\end{array}$ & $\begin{array}{c}\text { Beginning } \\
(\mathbf{\%})\end{array}$ & $\begin{array}{c}\text { Incorrect } \\
(\mathbf{\%})\end{array}$ \\
\hline Sophomore & 2.8 & 22.2 & 41.7 & 33.3 \\
Junior & 4 & 38 & 13.8 & 5.26 \\
Senior & 0 & 40.9 & 33.3 & 25.8 \\
Total Percentage & $\mathbf{2}$ & $\mathbf{3 5 . 5}$ & $\mathbf{3 8 . 2}$ & $\mathbf{2 4 . 3}$
\end{tabular}

Table 6 shows that only $2 \%$ of the responses belong to the mastery level. Most of the responses fell into beginning category (38.2\%) and emerging category (35.5\%). Preservice teachers who successfully met the mastery category explained the authenticity of the account as well as addressed the company's bias and its intention to promote their program and improve its image. As one preservice teacher wrote:

This account is a verified account, as can be seen from the blue tick next to the account name. I can trust this video as the source of information because this video is posted by the official account of the company. However, companies love to sugarcoat their words. This one is not an exception. I wouldn't believe what companies say unless they have actual proof because most of the oil companies do not really care about the environment. They are just making money by damaging the environment.

Most responses fit within the emerging category. They evaluated the source as the official account of the company but failed to detect the bias that influenced the 
company's commitment to the environment. They did not take into account British Petroleum's impact on the pollution.

\section{DISCUSSION}

Patterns of students' responses show a consistent lack of critical evaluation of the credibility of the sources. Many students struggled to engage in the process of reasoning, which required basic evaluations of the authors, sources, and evidence. We found ample evidence that students did not question who was behind the information. When they evaluated the information, they relied on the surface display of the information. Students considered the pictures in the website as the standard for judging the credibility of the information. Some of them mentioned that the oil company website provided reliable information because the website showed clear pictures of the company's program and multiple charts containing information. Only a few students recognized that the government website was more reliable while the non-government, especially a private company's website, was prone to bias. This result is in line with the previous studies, which pointed out that website appearance influenced students' thinking about the credibility of the information (McGrew \& Byrne, 2020; Nygren \& Guath, 2019, 2021; Wineburg \& McGrew, 2019).

Students' lack of awareness regarding who's behind the information was also evident in the way they evaluated the information from the social media. A few students questioned the credibility of sources of the WhatsApp post regarding Covid19. Not many of them questioned whether the information was really posted by a doctor. Most of their comments pointed to the content of the information. The students evaluated the information by comparing it with what they have known regarding the prevention of the Covid19 virus. While comparing between information is a common strategy, it is not effective in sifting the unreliable sources of information. This finding confirms the previous research, which has examined readers' uncritical response to the growing circulation of fake news and hoaxes in the WhatsApp (Herrero-Diz et al., 2020; Ilahi, 2019; Stefanone et al., 2019). They not only accepted the information without critical evaluation but also shared it with other people. This uncritical sharing of information is particularly widespread among young people who often share information in their WhatsApp group when the content reflects their interest, regardless of the credibility of the information (Herrero-Diz et al., 2020).

The results of this study also shed light on the students' ability to evaluate information from their frequently used digital platforms, i.e. YouTube and Instagram. With over 2 billion monthly users, YouTube has become the most accessed online video sites. Through its 15 years of existence, YouTube has developed from a video-dating profile site into a video-hosting platform that provides free space for all kinds of purposes. Due to its accessibility, popularity, and the possibility of gaining financial benefit, the use of YouTube ranges widely from entertainment purposes to academic endeavors. The benefits of using YouTube 
video as the sources of information come with challenges as well. Since YouTube has also been used as the channel to spread misinformation, hoaxes, and conspiracy theories, people have to be cautious about the information they view from the YouTube channel. Nicas explains the impact of YouTube video recommendations on what kinds of information are fed into our YouTube app. His journalistic investigation showed that YouTube's recommendations often directed viewers toward conspiracy theories even when they only accessed the mainstream news or information (Nicas, 2018).

As the Internet has increasingly become the place for people to access health information, YouTube has also gained traction as a popular site in times of pandemics. This phenomenon has two sites of the coin. On the one hand, public health offices can use this platform to promote best practices to protect us from the spread of infectious diseases. On the other hand, YouTube has become the fertile ground for misinformation and conspiracy theories during the COVID19 public health emergency. From The 69 English highly accessed Covid19 YouTube videos they screened in March 2020, Li, Bailey, Huyhn and Chan found that 27.5 percent contained non-factual information and reached 62 million views worldwide. Meanwhile, the informative and high-quality videos provided by government agencies did not garner a high number of views (Li et al., 2020).

Similarly, online surveys regarding the relationship between social media use and conspiracy beliefs among UK residents during Covid19 pandemic conducted by Allington, Duffy, Wessely, and Dhavan show a positive relationship between COVID19 conspiracy beliefs and the use of social media as a source of information. The study also highlights YouTube's problematic position as the source of health information. The respondents who accessed conspiracy videos on YouTube appeared to have underestimated the lethality of the novel Coronavirus (Allington et al., 2020; Krause et al., 2020).

Our findings have shown similar results; many students did not question the reliability of the claims made in the YouTube video. The focus group discussions have provided in-depth information about the students' experience of doing the tasks. Most students considered evaluating the YouTube video as the most challenging task. They found it challenging to understand the long video within such a limited time.

Furthermore, students' experiences with multiple types of online information have contributed to the way they approached the claims provided in the task. One senior student confidently stated that the YouTube video in task 5 was a conspiracy theory. He recognized this type of information because of his experience and interest in watching a video channel that discussed conspiracy theories. However, not many students have the tools to know the characteristics of dubious information and how to be critical of the information they encountered in the online environment. Some researchers have called for authoritative interventions to limit the spread of such 
dangerous health information (Lovari, 2020; Marchal \& Au, 2020), but there is only so much the governments could do to counter the fake news. At the end of the day, the consumers of the information have to strengthen their critical evaluation of the information.

\section{CONCLUSION}

Evaluating the credibility of online sources shown to be a challenge for many students. Students' tendency to trust what they read online without sufficient critical evaluation is alarming. In this age of digital information, being a civic member of global society mean being able to participate in an informed manner through the critical process of information. Our results point to the need to provide students with online critical literacy instructions. Despite having taken several reading classes in the program, the students still struggled to assess online reading materials, especially to determine the credibility of multimodal texts. While reading strategies of traditional (printed) texts are commonly taught, strategies for dealing with online information seemed to be lacking. To improve students' ability in evaluating online sources, reading and writing classes can be geared toward the analysis of multimodal texts, which include information delivered through video, images, and online texts. Moreover, students need to be supported with exposure to the critical inquiry of the sources. Instructors can demonstrate how to do a critical analysis of the sources and model the strategies for doing so online or in a contained environment of a language multimedia lab.

\section{ACKNOWLEDGMENT}

The research was funded by Sriwijaya University's Science, technology, and Arts Research Grant (SATEKS Universitas Sriwijaya) under the contract No.

0163.223/UN9/SB3.LPPM.PT/2020

\section{REFERENCES}

Aimah, S., \& Purwanto, B. (2019). The use of teachers' questioning strategies to stimulate students' critical literacy: A case of two English lecturers in Indonesia. Indonesian EFL Journal, https://doi.org/10.25134/ieflj.v5i1.1608

Allington, D., Duffy, B., Wessely, S., Dhavan, N., \& Rubin, J. (2020). Healthprotective behaviour, social media usage, and conspiracy belief during the COVID-19 public health emergency. Psychological Medicine. https://doi.org/10.1017/S003329172000224X

Alvermann, D. E. (2017). Social Media Texts and Critical Inquiry in a Post-Factual Era. Journal of Adolescent and Adult Literacy, 61(3). https://doi.org/10.1002/jaal.694

Baildon, M., \& Baildon, R. (2012). Evaluating Online Sources: Helping Students Determine Trustworthiness, Readability, and Usefulness. Social Studies and the 
Sary Silvhiany, et al

Young Learner, 24(4).

Beach, R., Boggs, G., Castek, J., Damico, J., Panos, A., Spellman, R., \& Wilson, N. (2020). Fostering Preservice and In-Service ELA Teachers' Digital Practices for Addressing Climate Change. Contemporary Issues in Technology and Teacher Education (CITE Journal), 20(1).

Breakstone, J., Smith, M., Wineburg, S., Rapaport, A., Carle, J., Garland, M., \& Saavedra, A. (2019). Students' civic online reasoning: A national portrait. Stanford History Education Group \& Gibson Consulting, November.

Brennen, J. S., Simon, F., Howard, P. N., \& Nielsen, R. K. (2020). Types, sources, and claims of COVID-19 misinformation | Reuters Institute for the Study of Journalism. Reuters Institute for the Study of Journalism.

Chaka, C. (2019). Re-imagining literacies and literacies pedagogy in the context of semiotechnologies. Nordic Journal of Digital Literacy, 14(1-2). https://doi.org/10.18261/ISSN.1891-943X-2019-01-02-05

Damico, J. S., \& Baildon, M. (2011). Content literacy for the 21st century: Excavation, elevation, and relational cosmopolitanism in the classroom. Journal of Adolescent and Adult Literacy, 55(3). https://doi.org/10.1002/JAAL.00028

Damico, J. S., Panos, A., \& Baildon, M. (2018). "I'm not in the truth business": the politics of climate change with pre-service teachers. English Teaching, 17(2). https://doi.org/10.1108/ETPC-05-2017-0081

Gustine, G. G. (2013). Designing and Implementing a Critical Literacy-based Approach in an Indonesian EFL Secondary School. International Journal of Indonesian Studies, 1(2001).

Hargittai, E., Fullerton, L., Menchen-Trevino, E., \& Thomas, K. Y. (2010). Trust online: Young adults' evaluation of web content. International Journal of Communication, 4, 468-494.

Head, A. J., DeFrain, E., Fister, B., \& MacMillan, M. (2019). Across the great divide: How today's college students engage with news. First Monday. https://doi.org/10.5210/fm.v24i8.10166

Herrero-Diz, P., Conde-Jiménez, J., \& Reyes de Cózar, S. (2020). Teens' Motivations to Spread Fake News on WhatsApp. Social Media and Society, 6(3). https://doi.org/10.1177/2056305120942879

Hobbs, R. (2010). Copyright clarity: How fair use supports digital learning. In Copyright Clarity: How Fair Use Supports Digital Learning. https://doi.org/10.4135/9781452219530

Ilahi, H. N. (2019). Women and Hoax News Processing on WhatsApp. Jurnal Ilmu Sosial Dan Ilmu Politik, 22(2). https://doi.org/10.22146/jsp.31865

Kalogeropoulos, A., Fletcher, R., \& Nielsen, R. K. (2019). News brand attribution in distributed environments: Do people know where they get their news? New Media and Society, 21(3). https://doi.org/10.1177/1461444818801313

Khairunissa, K. (2020). University Students' Ability in Evaluating Fake News on 
Critical Digital Literacy: EFL Students' Ability to Evaluate Online Sources

Social Media. Record and Library Journal, 6(2). https://doi.org/10.20473/rlj.v6-i2.2020.136-145

Krause, N. M., Freiling, I., Beets, B., \& Brossard, D. (2020). Fact-checking as risk communication: the multi-layered risk of misinformation in times of COVID19. Journal of Risk Research, 23(7-8). https://doi.org/10.1080/13669877.2020.1756385

Lee, N. M. (2018). Fake news, phishing, and fraud: a call for research on digital media literacy education beyond the classroom. Communication Education, 67(4). https://doi.org/10.1080/03634523.2018.1503313

Leeder, C. (2019). How college students evaluate and share "fake news" stories. Library and Information Science Research, 41(3). https://doi.org/10.1016/j.lisr.2019.100967

Li, H. O.-Y., Bailey, A., Huynh, D., \& Chan, J. (2020). YouTube as a source of information on COVID-19: a pandemic of misinformation? BMJ Global Health, 5(5). https://doi.org/10.1136/bmjgh-2020-002604

Lovari, A. (2020). Spreading (Dis)Trust: Covid-19 Misinformation and Government Intervention in Italy. Media and Communication, 8(2). https://doi.org/10.17645/mac.v8i2.3219

Lovelace, B. (2020, April 24). FDA issues warnings on chloroquine and hydroxychloroquine after deaths and poisonings reported. Https://Www.Cnbc.Com/2020/04/24/Fda-Issueswarnings-on-Chloroquine-andHydroxychloroquineafter-Serious-Poisoning-and-Death-Reported.Html.

MacFarquhar. (2016). A powerful Russian weapon: The spread of false stories. The New York Times.

Marchal, N., \& Au, H. (2020). "Coronavirus EXPLAINED”: YouTube, COVID-19, and the Socio-Technical Mediation of Expertise. Social Media + Society, 6(3). https://doi.org/10.1177/2056305120948158

Mbau, A. T., \& Sugeng, B. (2019). Critical Literacy for ELT in Indonesia: What EFL Teachers should be Aware of. Journal of English Language Teaching and Linguistics, 4(2). https://doi.org/10.21462/jeltl.v4i2.255

McDowell, Z. J., \& Vetter, M. A. (2020). It Takes a Village to Combat a Fake News Army: Wikipedia's Community and Policies for Information Literacy. Social Media and Society, 6(3). https://doi.org/10.1177/2056305120937309

McGrew, S., Breakstone, J., Ortega, T., Smith, M., \& Wineburg, S. (2018). Can Students Evaluate Online Sources? Learning From Assessments of Civic Online Reasoning. Theory and Research in Social Education, 46(2). https://doi.org/10.1080/00933104.2017.1416320

McGrew, S., \& Byrne, V. L. (2020). Who Is behind this? Preparing high school students to evaluate online content. Journal of Research on Technology in Education. https://doi.org/10.1080/15391523.2020.1795956

Metzger, M. J., Flanagin, A. J., \& Zwarun, L. (2003). College student Web use, perceptions of information credibility, and verification behavior. Computers 
Sary Silvhiany, et al

and Education, 41(3). https://doi.org/10.1016/S0360-1315(03)00049-6

Nagle, J. (2018). Twitter, cyber-violence, and the need for a critical social media literacy in teacher education: A review of the literature. In Teaching and Teacher Education (Vol. 76). https://doi.org/10.1016/j.tate.2018.08.014

Newman, N. . F. R. . S. A. . A. S. . \& N. R. K. (2020). Reuters Institute Digital News Report. Https://Www.Digitalnewsreport.Org.

Nicas, B. J. (2018). How YouTube Drives People to the Internet's Darkest Corners. Wall Street Journal.

Nygren, T., \& Guath, M. (2019). Swedish teenagers' difficulties and abilities to determine digital news credibility. Nordicom Review, 40(1). https://doi.org/10.2478/nor-2019-0002

Nygren, T., \& Guath, M. (2021). Students Evaluating and Corroborating Digital News. Scandinavian Journal of Educational Research. https://doi.org/10.1080/00313831.2021.1897876

Office of Communication. (2016). The changing face of online news. Https://Www.Ofcom.Org.Uk/_data/Assets/Pdf_file/0022/115915/ScrollingNews.Pdf.

Potter, J., \& Gilje, Ø. (2015). Curation as a new literacy practice. In E-Learning and Digital Media (Vol. 12, Issue 2). https://doi.org/10.1177/2042753014568150

Purcell, K., Rainie, L., Mitchell, A., Rosenstiel, T., \& Olmstead, K. (2010). Understanding the participatory news consumer: How internet and cell phone users have turned news into a social experience. Pew Research Center.

Roser, M. . R. H. . and O.-O. E. (2015). Internet. Https://Ourworldindata.Org/Internet.

Rusydiyah, E. F., Purwati, E., \& Prabowo, A. (2020). How to use digital literacy as a learning resource for teacher candidates in Indonesia. Cakrawala Pendidikan, 39(2). https://doi.org/10.21831/cp.v39i2.30551

Schaeffer, K. (2020). Nearly three-in-ten American believe Covid-19 was made in a lab. Https://Www.Pewresearch.Org/Fact-Tank/2020/04/08/Nearly-Three-inTen-Americans-Believe-Covid-19-Was-Made-in-a-Lab/.

Setyaningsih, E. (2019). Bringing critical literacy into tertiary EFL reading class. Indonesian Journal of Applied Linguistics, 9(2). https://doi.org/10.17509/ijal.v9i2.20220

Silvhiany, S. (2019). Critical Digital Literacies in Education 4 . 0: Preparing Students for the Uncertainties of Post-Truth World. LINGUA, 19(2), 102-109. https://ejournal.unsri.ac.id/index.php/lingua/article/view/11092/5251

Silvhiany, S., Huzaifah, S., \& Ismet. (2021). Developing Online Critical Literacy Assessment for EFL Learners. https://doi.org/10.2991/assehr.k.201230.134

Stefanone, M. A., Vollmer, M., \& Covert, J. M. (2019, July 19). In News We Trust? Proceedings of the 10th International Conference on Social Media and Society. https://doi.org/10.1145/3328529.3328554

Sundar, S. S. (2008). The MAIN model: A heuristic approach to understanding 
technology effects on credibility. Digital Media, Youth, and Credibility. https://doi.org/10.1162/dmal.9780262562324.073

Who.int. (2021). managing-the-covid-19-infodemic-promoting-healthy-behavioursand-mitigating-the-harm-from-misinformation-and-disinformation. Who.Int.

Wineburg, S., \& McGrew, S. (2019). Lateral reading and the nature of expertise: Reading less and learning more when evaluating digital information. Teachers College Record, 121(11). 